\title{
Forvandlingens psykoanalyse
}

I november 1912 sad forfatteren og forsikringsmanden Franz Kafka på sit hummer hos forældrene i Prag og skrev »Die Verwandlung" (udg. 1915), der sammen med fortællingerne »Die Urteil « og »Der Heizer", alle skrevet samme efterår, af Kafka selv blev opfattet som gennembruddet til en mere sikker stil. Samme syn har den internationale litterære kritik antaget, og siden har "Die Verwandlung « - som generelt når det drejer sig om Kafkas værker - været genstand for en uhyre biografisk forskning, der især har villet påvise umiskendelige sammenfald mellem fortællingens hovedperson, Gregor Samsa, og Kafkas private jeg. Denne artikel er ikke en biografisk kortlægning af Kafka, men en klassisk freudiansk-orienteret psykoanalyse af den betydningstatte fortælling "Die Verwandlung «, hvor interessen retter sig mod fortællingens psykiske miljø, herunder først og fremmest mod hovedpersonens intrapsykiske og interpersonelle konflikter. Det er således subjektet-i-teksten og ikke subjektet bag teksten, den empiriske forfatter, der er analysens genstand.

\section{Forvandlingen}

»Die Verwandlung « indleder med en forvandling. Fortællingens hovedperson, ungkarlen Gregor Samsa, vågner op en morgen efter urolige drømme og oplever sig selv "zu einem ungeheueren Ungeziefer verwandlet« (s.56), dvs. forvandlet til et kæmpestort kryb/skadedyr.

Forvandlingen manifesterer sig som kroppens forvandling, hvorimod Gregors bevidsthed forbliver menneskelig, hvilket betyder at han er i stand til at konstatere at noget er ændret, uden at han dog søger at forstå forvandlingen.

Forvandlingen ytrer sig som en afgørende forhindring for hovedpersonen $i$ at gå på arbejde og dermed udføre de samme forpligtelser som før forvandlingen. Idet Gregor Samsa, i en kort overgang som kommis, men snart som handelsrejsende, siden farens ${ }^{1} \emptyset$ konomiske fallit fem år tidligere har fungeret som familiens forsørger, samt med sin indkomst har afbetalt på 
farens gæld efter dennes forretningsmæssige sammenbrud, betyder forvandlingen altså samtidig et eklatant brud på familiens socio-økonomiske struktur.

I forvandlingens første time retter Gregors refleksioner sig især mod netop arbejdet, og .vi er her vidne til en absolut kategorisk og bitter forbandelse af det. Endog erfarer vi, at Gregor alene beholder sit job for forældrenes skyld:

»Wenn ich mich nicht wegen meiner Eltern zurückhielte, ich hätte längst gekündigt, ich wäre vor den Chef hin getreten und hätte ihm meine meinung von Grund des Herzens aus gesagt. Vom Pult hätte er fallen müssen!« (s.57)

Arbejdet opleves altså som tvang. Og det er på dette tidspunkt, kort efter forvandlingen, genstand for bevidste og manifeste angreb fra Gregors side. Først og fremmest retter aggressionen sig mod den chef, der som en demonstration af den hierarkiske magtstruktur taler ned til sine ansatte fra en pult.

\section{Overjeg'ets dominans}

Samtidig markerer skyldfølelser og samvittighedsangst sig. Det kommer bl.a. til udtryk $\mathrm{i}$ hans kamp for alligevel at komme ud af sengen for at nå det næste tog til arbejdet, samt i hans overbevisning om at blive offer for utallige udtalte (fra chefen) og uudtalte (fra forældrene) bebrejdelser, såfremt han melder sig syg. Gregor er i denne situation styret af det overjeg, der har allieret sig med samfundet (chefen), og som straffer jeg'et med samvittighedsangst.

Overjeg'ets dominans viser sig tillige i hans voldsomme forsøg på at camouflere forvandlingen ved at indpasse det skete til det bevidste jeg's fornuftslogik. Han benægter og rationaliserer sin kropsoplevelse ved bl.a. at henføre den til en drømmeagtig tilstand, der kan ophæves med søvn og ny opvågning: "Wie wäre es, wenn ich noch ein wenig weiterschliefe und alle Narrheiten vergäße« (s.56).

Men Gregor kan i den forvandlede tilstand ikke indtage sin vanlige sovestilling og kan derfor ikke sove videre. Med andre ord: Han kan ikke fortrænge. Kroppen, som således markerer sig med en modsatrettet meddelelse til Gregor - der af Gregor udlægges som et "kan ikke« (»gänzlich undurchführbar«, s.56), men snarere må antages at være et »vil ikke« - fungerer som en nægtelse af at adlyde overjeg'ets forsøg på at 
fortrænge v.hj. af rationaliseringer. Fortrængningsforsøget er igen evident, da Gregor konstaterer, at også hans stemme har ændret sig. I den har der blandet sig "wie von unten her, ein nicht zu unterdrückendes, schmerzliches Piepsen« (s.58). På denne ændring har Gregor ligeledes en logisk forklaring, nemlig at det ikke er andet end tegn på en begyndende forkølelse.

\section{Gregors spaltning}

Gregors fortrængningsfors $\emptyset \mathrm{g}$ mislykkes altså især, fordi kroppen i sin insisterende synlighed og uafhængighed af den bevidste vilje forhindrer det. Der er tale om en spaltning mellem bevidsthed og krop, mellem den pligtopfyldende forretningsmand og dyret, hvilket i fortællingens begyndelse understreges med Gregors besvær med at kontrollere sin forvandlede krop, hvis mange ben bevæger sig »wie freigelassen« (s.59). Idet kroppen gentagne gange hindrer ham $\mathrm{i}$ at stå op, virker den emanciperet $\mathrm{i}$ forhold til såvel den ydre (arbejdsforpligtelser, opfyldelse af forsørgerrollen) som den indre (Gregors overjeg) tvang. Den frihedsmetaforik, der således er knyttet til kroppen, udfoldes særligt i fortællingens kap. to, hvor Gregor opnår så stor kontrol med kroppen, at han kan udnytte dens bevægelsesfrihed og kravle rundt på vægge og loft i en »fast glücklichen Zerstreutheit« (s.78-79).

Om dette kan vi nu konkludere, at Gregors forvandlede krop er en manifestation af hans egentlige $\emptyset$ nsker og behov og dermed en synliggørelse af hans protest mod den tvangsprægede livsførelse. Denne ret beset åbenlyse konklusion drager Gregor imidlertid ikke selv. Gregor er bevidst om en protest, men p.g.a. det bevidste jeg's uvilje mod at erkende forvandlingen, kædes protesten ikke sammen med kroppens sprog, der tværtimod søges fortrængt og camoufleret.

\section{Det fortrangtes tilbagevenden}

I dette perspektiv er det nærliggende at anskue kroppen som en manifestation af det'et, dvs. som det fortrængtes tilbagevenden. Såvel kroppens nægtelse af at sove videre, dvs. adlyde overjeg'ets fortrængningsforsøg, som den piben i Gregors stemme, der ligesom kommer von unten« (s.58), og som ikke kan undertrykkes, profilerer denne synsvinkel. Også valget af dyret som et udtryk for den forvandlede tilstand $g \emptyset r$ en parallelisering mellem drifter og den forvandlede del af Gregor oplagt. Den forvandlede krop synes at være blevet en ovenud adækvat og somatisk symboliseret repræsentant for 
- eller et symptom på - det fortrængtes tilbagekomst.

\section{Forvandlingens flugtmotiv}

Idet forvandlingens sprog holdes adskilt fra den bevidste protest og ønsket om frihed er forvandlingen i høj grad flugtmotiveret. Den repræsenterer en flugt ikke blot fra det tvangsprægede arbejde, men helt specifik fra ansvaret for protesten, og den betegner i sidste instans et forsøg på flugt fra netop samvittighedsangsten og skyldfølelser. Dette er tydeligt i Gregors behov for at blive betragtet som syg, hvilket bl.a. kommer til udtryk i den beroligende virkning, det har på ham at familien vil hente læge og smed: »Er fühlte sich wieder einbezogen in den menschlichen Kreis...« (s.64).

Til trods for at Gregor kort forinden tilbageviste muligheden af at melde sig syg og ikke havde intentioner om at åbne døren, men tværtimod glæder sig over sin »vom Reisen übernommene Vorsicht, auch zu Hause alle Türe während der Nacht zu versperren « (s.58), er det et presserende ønske hos ham at blive set (smedens opgave: At åbne døren) og at blive erklæret syg (lægens opgave: At stille diagnosen). Herved kan atter skabes et rationelt, dvs. sygdomsbegrundet, forsvar mod samvittighedskvaler. Dette ønske har dog sin kilde i et andet og mere oprindeligt ønske om integration og accept.

\section{Gregor mellem integration og alienation}

Da det endelig er lykkedes Gregor at komme ud af sengen, er hans beslutning om alligevel at forsøge at åbne døren ledsaget af en iver efter at se, hvilke reaktioner han kan vække:

"Würden sie erschrecken, dann hatte Gregor keine Verantwortung mehr und konnte ruhig sein. Würden sie aber alles ruhig hinnehmen, dann hatte auch er keinen Grund sich aufzuregen, und konnte, wenn er sich beeilte, um acht Uhr tatsächlich auf dem Bahnhof sein« (s.64).

Gregors opstilling af to mulige reaktioner - forskrækkelse versus rolig affindelse - på hans forvandling til kryb er helt central. Det viser hans muligheder som dyr; "alles« relaterer sig til forvandlingen som en manifestation af fortrængte drifter, som familien enten kan stigmatisere eller acceptere. Deres forskrækkelse betyder Gregors alienation, men også hans frihed for ansvar. Omvendt betyder deres affindelse accept og dermed er 
vejen åben for mulig integration af det fortrængte. Men det er den negative reaktion, han får. Og således er istedet vejen åben for en flugt ind $\mathrm{i}$ sygdommen som en måde, hvorpå han på én og samme tid kan manifestere de fortrængte $\emptyset$ nsker, såvel som protesten mod deres manglende accept.

\section{Kroppen som en manifestation af fortrangt aggressivitet}

Da Gregor kommer til syne i sin forvandlede skikkelse, står Gregors bevidste jeg og familien/prokuristen overfor hinanden med absolut kontrare oplevelser af det, der sker. I henhold til Gregor selv er han den bønfaldende og forsvarsløse, og prokuristen er autoriteten - dommeren eller bøddelen der kan afgøre Gregors og familiens ganske skabne. For prokuristen derimod er Gregor den aggressivt angribende, opfyldt af hævnfølelser. Prokuristens skræk og paniske flugt bevidner, at han på det nærmeste frygter for sit liv.

Da Gregor følger efter prokuristen $i$ den bevidste hensigt at berolige ham og vinde ham for sig, oplever han med et at kunne beherske sin krop, som han vil. Med et skrig falder han ned på gulvet og føler for første gang siden forvandlingen »ein körperliches Wohlbehagen« (s.68). Denne overensstemmelse med kroppen i en forfølgelse demonstrerer på bedste vis, at Gregors forfølgelse faktisk er en udfoldelse af protesten og de aggressioner, som kort forinden var manifeste og bevidste. Dette forstår også familien. Moren farer forfærdet op, skriger om hjælp, viger baglæns, vælter kaffekanden, hvorved kaffen løber ud over bordet og ned på gulvet. Gregor selv forstår det imidlertid ikke. I handlingsøjeblikket har han ikke blot fortrængt aggressiviteten, men besat den med præcis den modsatte emotive holdning, hvorfor han også i forhold til moren har en ganske anden selvoplevelse, nemlig som den blide, kontaktsøgende søn: »Mutter, Mutter, sagte Gregor leise, und sah zu ihr hinauf $\ll$ (s.68).

Spaltningen mellem krop og bevidsthed, mellem ubevidste motivationer og bevidste intentioner, er her særlig tydelig og udpraget neurotisk, idet den har et nødvendigt formål - nemlig at isolere og fortrænge den forvandlede krops sprog, så ansvar og skyldfølelser i nogen grad kan undgåes. Og muligheden af at anskue den forvandlede krop som det fortrangtes tilbagevenden, dvs. som et symptom - i dette perspektiv som et symptom på fortrængt aggressivitet - kan bekræftes. Familien opfatter ganske enkelt Gregor som uhyggelig aggressiv, fordi han er det. Uden at vide det har han overskredet fortrængningsbarrieren, metaforisk udtrykt i hans faktiske overskridelse af tærsklen mellem sit eget rum og familiens dagligstue. 
Men Gregors aggressioner er ikke rettet mod familien. De er alene rettet mod det ensformige arbejde og chefens autoritære holdning. Familien derimod er genstand for en voldsom bekymring for, hvordan det nu skal gå dem, og betragtes af Gregors bevidste jeg som »der ganzen unschuldigen Familie« (s.61). Hans bekymringer og noget selvudslettende hensyntagen, der bl.a. kommer til udtryk $\mathrm{i}$ hans vane med at tildxkke sin dyriske krop med et lagen, når søsteren kommer ind $\mathrm{i}$ værelset for at rengøre det, kan imidlertid i netop sin overdrevne karakter anskues som en reaktionsdannelse mod aggressive impulser rettet mod familien, ligesom behovet for at holde dem skyldfri uvægerligt ligner en klamren sig til et idealiseret forældrebillede, som truer med at krakelere under id'ets pres.

\section{Gregors isolation}

Den frihed, som forvandlingen giver Gregor ved at forløse ham fra den tvangsdefinerede fors $\emptyset$ rgerposition, er imidlertid begrænset af den isolation, fremmedgørelse og afhængighed, som forvandlingen også er. Værelset fungerer her som en prægnant metafor for isolationen, Samt som et udtryk for familiens stigmatisering og udstødelse af det, som forvandlingen repræsenterer og som truer den familiære stabilitet, hvilket understreges med at dørene, efter at Gregor har vist sig for familien, fremover er låst udefra. Og i fortællingen anvendes da også direkte udtrykket »Gefangenschaft« (s.71) om Gregors situation siden forvandlingen. Fangenskabet må samtidig forståes på baggrund af den umulige intrapsykiske situation, som forvandlingen har placeret hans jeg i, nemlig i den hasblasende position som administrator af de impulser fra det'et, der med forvandlingen truer med at gennembryde fortrængningsbarrieren, og som er i opposition til såvel hans jeg som hans strenge overjeg. Gregors ord til prokuristen - »Ich bin in der Klemme« (s.66) - er ganske adækvate. Gregor er vitterlig i klemme, hans jeg er i klemme.

\section{Regression til den anale fase}

Gregors forkærlighed for halvrådne madvarer efter forvandlingen er et indicium for disse driftsimpulsers karakter og fixeringspunkt. Lysten til det ulækre er et klart billede på infantile driftsønskers gennembrydelse af fortrængningsbarrieren, især når det betones, at denne lyst ikke bare kan sammenholdes med en infantil interesse for egne ekskrementer, men simpelt 
hen må udlægges som en sådan lyst, der her udlades via forskydning til den ulakre føde. Det betyder, at det er muligt at parallelisere det fortrængtes tilbagevenden med en regression til den anale fase, understreget af at det $i$ fortællingens kap. tre, hvor Gregors værelset har forvandlet sig til dynger af skidt og støv, endog $\mathrm{i}$ et umiskendeligt fæcessprog hedder at »hie und da lagen Knäuel von Staub und Unrat« (s.88). Direkte oversat betyder »Unrat« bl.a. uhumskheder.

Denne $\mathrm{i}$ begyndelsen ukomplicerede og lystbetonede hengivelse til den ulækre føde erstattes dog snart af forsagelse, hvilket dog fortsat kan relateres til den anale fase. Forsagelsen er motiveret af et $\emptyset$ nske om at skabe opmærksomhed og vakke bekymringer. Dette er helt evident, idet Gregors livsfornægtende adfærd på påfaldende vis tiltager parallelt med at familien ikke længere ofrer ham samme opmærksomhed som i forvandlingens første tid. Ved i den grad at gøre opmærksom på sin egen forhutlede tilstand som fornægter af føde, tilgodeser Gregor den fortrængte aggression. Det er ganske enkelt en måde at straffe familien på, m.a.o. en måde hvorpå netop anal-sadistiske driftsmål som beherske/besidde får sin udløsning. Ikke en ukompliceret måde, men en neurotisk magtudfoldelse - en tilfredsstillelse af det regressive dominansbehov, hvor såvel primærgevinsten som sekundærgevinsten er sikret.

Specielt tydeligt er imidlertid forvandlingens anale atiologi, når forvandlingen fungerer som en forhindring for Gregor $i$ at tjene penge til familien og betale farens fæld. Tilbageholdelsen af penge kan relateres til den anale fases tilbageholdelse af ekskrementer, hvilket psykisk tilgodeser ønsket om aktivt at kontrollere og dominere.

\section{Gregors skyldkompleks}

Dette aspekt indicerer samtidig at det, der er på færde $\mathrm{i}$ »Die Verwandlung «, er en aktiv-passiv konflikt i relation til faren - altså en magtkamp. Et kamp, der får sine klimakspunkter med fortællingens faktiske strafscener, hvor det er faren, der står som den straffende instans og med direkte vold driver Gregor tilbage til varelset to af de gange, han er brudt ud. Især farens anden korporlige afstraffelse, som markerer udgangen på fortællingens kap. to, leverer materiale til en belysning af konflikten, fordi Gregor her konfronteres med en radikal anderledes oplevelse af sin far. Gregor, der husker sin far som en svag og træt gammel mand, der opholder sig det meste af tiden i sin seng eller sin lænestol, oplever ham her som en oprejst, stram uniformklædt magtfigur med et borende opmærksomt blik, og med det ellers uredte hår 
kæmmet $\mathrm{i}$ en præcis frisure (s.83-84). Således konfronteret med autoriteten par excellence, med den inkarnerede faderlov, fors $\emptyset$ ger Gregor i begyndelsen at undvige faren. Alligevel $g \emptyset r$ han ikke brug af sin mest indlysende flugtmulighed - væggene. Dette får sin manifeste forklaring med, at Gregor ikke ønsker at vække en større vrede hos faren, dernæst at han af ren og skær udmattelse på grund af løberiet frem og tilbage næsten har glemt »fast schon vergessen hatte« (s.84), at han har mulighed for at flygte op ad væggene. Og da faren begynder at bombardere Gregor med abler, bliver Gregor ganske enkelt stående ud fra devisen:

»ein weiterlaufen war nutzlos, denn der Vater hatte sich entschlossen, ihn zu bombardieren« (s.84)

Såvel forglemmelsen som overbevisningen om det nytteløse i at flygte er imidlertid absurde forklaringer. Det er uholdbare forsøg på rationalisering, der dakker over et latent masochistisk strafbehov og vidner om et voldsomt skyldkompleks. Når forholdet mellem far og søn i »Die Verwandlung« nærmere analyseres bliver det da også evident at den magtkamp, som strafbehovet og farens åbenlyse brutalitet artikulerer, har en dybereliggende seksuel komponent.

\section{Magtkampen mellem far og $s \emptyset n$}

I betragtning af at faren med Gregors forvandling dermed også synes at forvandle sig, ligesom han tager arbejde som bankbud og atter bliver en del af samfundet, vil en umiddelbar psykoanalytisk udlægning måske være, at forvandlingen muligg $\emptyset \mathrm{r}$ farens generobring af sin aktive forsørgerposition, m.a.o. sin socialiserede fallisk-genitale position, samt at forvandlingen er Gregors tilsvarende tab. Som vi skal se, konsolideres denne udvikling godt nok med Gregors død, men det er en overfladebetragtning, der ikke tager tilstrækkelig højde for teksten i sin helhed.

For farens uniform konnoterer ganske vist magt, men det er kun en buduniform, og den kan sættes i modsætning til en anden uniform i fortællingen, nemlig billedet af Gregor fra militærtiden, »die ihn als Leutnant darstellte, wie er, die Hand am Degen, sorglos lächelnd, Respekt für seine Haltung und Uniform verlangte« (s.66). Dette billede vidner om en anden gloriøs forhistorie, som går tilbage til tiden før farens fallit - en tid med en ganske anden social status, og for Gregor en sorgløs tid. Alene af den grund kan denne tid modstilles tiden efter falliten, hvor Gregor nok udfylder en 
aktiv forsørgerposition, men kun gør det af pligtf $\emptyset$ lelse, dvs. indre tvang, og uden følelse af at blive respekteret, hvilket hans bitterhed overfor chefen klart tilkendegiver. Desuden er han kun en handelsrejsende, ganske underordnet indenfor magthierarkiet. Det, der på overfladen synes at være en aktiv bemægtigelse af farens position, er altså tværtimod en negativ defineret position. Gregors forvandling som en manifestation af hans protest kan i dette perspektiv specifikt betegnes som en protest mod den far, som efter fallitten sender sin søn ud i en underordnet samfundsposition for selv at bevare en vis værdighed. Og Gregor betaler af på farens gæld. Hans rolle er altså dirigeret af faren, som derved kompenserer for de ydmygelser, han led ved fallitten og således fastholder sin autoritære status. Gregors passivoplevelser af faren før forvandlingen synes altså især at være et billede, der skal beskytte ham mod en erkendelse af farens reelle magt indenfor familiens system og dermed mod Gregors egen afmagt og protesten mod den. Anskuet fra Gregors side - omend det stadig er ubevidst - synes samfundets magthierarki at være reproduceret i familien, hvorfor hans aggressioner imod chefen samtidig må anskues som aggressioner rettet imod faren.

Gregors far synes at have en ubevidst viden om denne forvandlingens sammenhæng. Derfor værger han sig mod at tage sin uniform af og gå $\mathrm{i}$ seng om aftenen, for istedet at sidde iklædt som en soldat, der holder vagt. Dette gælder selv om uniformen p.g.a. dette overforbrug snart bliver temmelig beskidt - en klar tilkendegivelse af, at uniformen er udtryk for en krampagtig demonstration af og klamren sig til magten, hvilket ikke ville have været nødvendigt, såfremt hans autoritære position ikke var truet. Men den er truet. $\mathrm{Og}$ den er truet af Gregor, der med forvandlingens regression til den anale fase, praget af polariteten beherske/beherskes, synliggør en aggressiv og infantil protest mod autoriteter, dvs. netop mod at blive behersket. Af samme grund er den beskidte uniform genstand for en helt abnorm opmærksomhed fra Gregor:

»Gregor sah oft ganze Abende lang auf dieses über und über fleckige, mit seinen stets geputzten Goldknöpfen leuchtende Kleid« (s.86).

En voyeuristisk lyst, forbundet med at den beskidte uniform for Gregor bevidner farens forfald.

Forvandlingen er altså en trussel mod den faderlige autoritet og dermed mod hele magtstrukturen i en typisk konstitueret kernefamilie. Uden at ville erkende det, fors $\emptyset$ ger Gregor at foretage det, han med en sadistisk metafor kalder »der große Schnit« (s.57), og som vil sige en konsekvent frigørelse fra den ydmyge position, der kan betegnes som symbolsk kastreret og derfor 
sættes i modsætning til det ønske, militærbilledet af ham konnoterer: Respekt for holdningen og uniformen, m.a.o. respekt for den falliske positur.

\section{$\emptyset$ dipal problematik - en urscene}

Udgangen på fortællingens kap. to, hvor faren bombarderer Gregor med æbler, er morens mellemkomst. Kun klædt i chemise og mens skørterne glider af hende, iler hun hen til faren, som hun sluttelig omfavner »in gänzlicher Vereinigung mit ihm« (s.85). En sådan fuldstændig forening af kvinde og mand, mor og far, er en imitation af et samleje. En urscene. Gregors synssvigten i denne scene er et billede på hans forsøg på at fortrænge det, han ser, og dermed en klar tilkendegivelse af hans ubehag. M.a.o. indikerer Gregors synssvigten, at konflikten i forhold til faren også er af ødipal karakter, og at det, han forsøger at fortrænge eller fornægte, er urscenens tematisering af et tab, nemlig dens tematisering af hvem moren tilhører.

\section{Seksuel bemagtigelsestrang}

Konfliktens ødipale struktur kan illustreres med en nærmere analyse af årsagen til og virkningen af farens straf $i$ denne scene. Han straffer Gregor for udbruddet fra værelset og dets konsekvenser, nemlig morens besvimelse, som sker i det øjeblik, hun ser Gregor presse sig ind mod hans billede af en pelsklædt kvinde, hvilket »seinem heißen Bauch wohltat« (s.82). Akten har altså seksuelle konnotationer. Og billedets centrale betydning for Gregor og fortællingens tematik anslåes, idet det på udførlig vis omtales på allerede fortællingens første side:

»Es stellte eine Dame dar, die mit einem Pelzhut und einer Pelzboa versehen, aufrecht dasaß und einen schweren Pelzmuff, in dem ihr ganzer Unterarm verschwunden war, dem Beschauer entgegenhob« (s.56).

Med fremhævelsen af at hele underarmen er forsvundet ind i muffen er billedet voldsomt seksualiseret. Armen har en fallisk betydning og foregriber således Gregors akt, der må udlægges som en demonstration af en seksuel bemagtigelsestrang. $\mathrm{Og}$ at dette begær retter sig mod moren, indikerer hendes besvimelse, som netop tydeliggør, at hun har forstået handlingen som 
en seksuel farvet objektbesættelse. Betegnende nok hedder det, at Gregor »saß auf seinem Bild« (s.82, fremhæevelsen er min).

Derfor må han straffes af faren. Og han straffes med abler, dvs. med den - ifølge den ikoniske fremstilling - forbudte frugt, som effektuerer syndefaldet og den menneskelige skyld. Eblet er et symbol på Gregors skyld, straffen for hans forsøg på at overskride et forbud, nemlig incestforbudet. At Gregor selv er overbevist om, at faren vil udlægge hans adfærd som en »Gewalttat« (s.83), bekræfter dette ødipale perspektiv.

Det ene able trænger ind i Gregors ryg og bliver siddende »als sichtbares Andenken im Fleische« (s.85). Idet dette æble bliver årsagen til at Gregor mister sin fulde førlighed og i sidste instans også bliver medvirkende til hans død, idet såret danner infektioner, er det tydeligt, at ablebombardementet også billedeligg $\emptyset r$ farens forsøg på at kastrere den søn, der ved en udfoldelse af sine aktive driftsmål stræber mod at indtage farens seksuelle plads indenfor det familiare system.

Fortællingens ødipale problematik forklarer Gregors strafbehov i forhold til faren, som herved får en seksuel komponent som straffen for det forbudte incestuøse moderbegar. Tilstedeværelsen af denne problematik er samtidig udmærket $\mathrm{i}$ overensstemmelse med min anskuelse af Gregors forvandling som en regression til den anale fase, dvs. til netop den fase i den psykoseksuelle udvikling, hvor Ødipuskomplekset konstitueres.

\section{Demonstration af en fallisk seksualitet}

Seksuelle $\emptyset$ nsker er imidlertid allerede billedligjort med Gregors første udbrud fra varelset, hvor han drejer nøglen rundt med munden. Åbningen er et brud med den isolation i varelset, som Gregor har et ambivalent forhold til, idet isolationen fritager ham fra de sædvanlige forpligtelser og dog gør ham fremmed i negativ forstand. I denne ødipale sammenhang får ambivalensen et klart seksuelt indhold. Således må Gregors mærkværdige vane med at holde dørene låst selv hjemme hos forældrene udlægges som en angst for farens hæun, altså som kastrationsangst. Omvendt er behovet for at åbne døren motiveret af ønsket om at komme nær på moren. Det gælder således også dette første udbrud fra værelset, hvor nøglen associativt er ækvivalent med penis og nøglehullet med vagina, hvorfor scenen artikulerer et aktivt og fallisk driftsønske om heteroseksuelt samleje. Det acceptønske, som jeg har påpeget at Gregors tanker før åbningen af døren blotlægger, og som motiverer den endelige åbning, er altså accepten af den falliske seksualitet, dvs. præcis den seksualitet som billedet af ham fra militærtiden 
konnoterer, og som kan muliggøre hans erobring af farens plads i forhold til moren. Åbningen og den derpå følgende forfølgelse af prokuristen er en demonstration af seksuel potens eller mere precist: En demonstration af at han $i k k e$ er kastreret.

Det »große Schnitt« (s.57), som Gregor ser frem til, er et aggressivt ønske om hævn over den far, der i hvert fald symbolsk har kastreret ham. Indenfor denne ødipale struktur får ønsket en særlig betydning, nemlig som en verbalisering af substitutionsønsket, hvilket betyder en samtidig symbolsk kastration af faren. Et hug, et snit.

Som en reaktion på Gregors udbrud knytter faren derfor næven med et fjendsk udtryk, og scenen kulminerer med hans straf med prokuristens stok. Et borgerligt og fallisk symbol, der skal demonstrere den faderlige autoritet og seksuel overlegenhed. Det er en brutal gengældelsesaktion, en kastrationsakt, der kaster Gregor blødende tilbage i værelset.

Farens demonstration af seksuel overlegenhed er understeget af, at han udstøder hvislelyde som en vild, dvs. anvender drifternes sprog. Pracis denne larm er derfor frygtelig enerverende for Gregor:

»es klang schon hinter Gregor gar nicht mehr wie die Stimme bloß eines einzigen Vater« (s.69)

Fordrivelsen og afstraffelsen er altså fader-institutionens, i dette tilfælde det borgerlige patriarkats stigmatisering af den, der ikke indordner sig under faderloven, men søger at sanktionere den ved en overtradelse af incestforbudet.

\section{Gregors latente homoseksualitet}

Men lad os gentage scenen.

Farens slag med stokken er »einen jetzt wahrhaftig erlösenden starken Stoß«, som tildeles »von hinten«, mens Gregor sidder hjælpeløst fanget $i$ døråbningen, og slaget slynger ham »heftig blutend « ind i værelset (s.70, fremhævelsen er min).

Strafscenen synes med disse fremhævelser af fă en anden seksuel drejning, nemlig som et voldeligt coitus per anum, hvor faren er den aktivt indtrængende og Gregor den underkastede, som penetreres af den falliske stok.

Sammenholdes denne interpretation med Gregors masochistiske strafbehov, synes hans masochisme ikke blot at vare af moralsk art, men den 
moralske masochisme synes i nogen grad at være blevet reseksualiseret og udtrykker en samtidig feminin indstilling overfor faren, dvs. en latent homoseksualitet, hvorfor straffen netop opleves som forløsende, dvs. er lystbetonet.

Denne seksuel-masochistiske binding må dog udlægges som en reaktionsdannelse mod det aktive Ødipuskompleks. M.a.o. er der tale om en aktiv-passiv omvending som et forsvar mod den kastrationsfare, som farens optraden udgør. Dette er samtidig et aspekt, der tydeliggør, i hvor høj grad Gregor er bøjet under sin fars autoritet. Istedet for at frigøre sig, må Gregor gribe til aktiv-passiv omvendingen som et forsvar. Og fordi Ødipuskomplekset således $\mathrm{i}$ såvel sin negative (homoseksuelle) som positive (heteroseksuelle) udformning er uafviklet, er Gregor ikke i stand til at overføre sin libido til et fremmed seksualobjekt, dvs. kanalisere den ud af familiens lukkede rum. Istedet frier han »ernsthaft, aber zu langsom« (s.87) og derfor for sent til en kvinde udenfor familiens system. Kun Gregors søster kan, som vi skal se, udgøre et andet kærlighedsobjekt. Og da alene som en erstatningsfigur i en videreførelse af det $\varnothing$ dipale drama.

Gregors passive drifsmål kan ligeledes iagttages i hans forhold til den pelsklædte kvinde. Hendes underarm har - som allerede påpeget - fallisk karakter, hvorfor hans idealiserede forhold til hende røber et masochistisk behov for at underlægge sig den falliske kvinde. Det er altså udtryk for en feminin og passiv indstilling.

\section{Gregors fetichisme}

Forholdet til dette billede rummer samtidig det dybeste lag i Gregors neurose, nemlig et psykotisk forsvar mod kastrationskomplekset.

Idet billedet er besat med libidinøse forestillinger, og idet underarmen symboliserer penis, kan dyrkelsen nemlig nærmere betegnes som fetichisme. I overensstemmelse med en klassisk psykoanalytisk forståelse af fetichisme, hvor fetichen som. symbolsk ækvivalent med penis installeres for at ophæve kvindens penismangel, er Gregors forhold til den falliske kvinde et fors $\emptyset \mathrm{g}$ på fornægtelse af at kvinden, e.g. moren, er kastreret.

Denne fornægtelse af dikotomien fallisk/kastreret er en primitiv forsvarsmekanisme, der skal forsvare ham mod en erkendelse af kastrationsmulighed overhovedet og istedet fastholde et billede af en magtfuld moderskikkelse som såvel identificeringsobjekt som erotisk objekt, uden rivalisering med en tredie instans - faren. M.a.o. er det et forsøg på at undgå den ødipale moderkærligheds modifikation ved kastrationsfare og istedet række tilbage 
mod en mere eksklusiv forening med moren, nemlig med den mor, som netop i den anale fase ofte tilskrives en penis. Denne tilskrivning sker ved en symboliseringsproces mellem det første partialobjekt, moderbrystet, og de senere: fæces, penis, barn.

En symboliseringsproces mellem bryst, fæces og penis kan direkte iagttages i Gregors første udbrud fra værelset. Min udlagning af udbruddet som en demonstration af fallicitet er ikke udtømmende, for Gregor drejer den nøgle, der symboliserer penis rundt med munden, hvilket fører tilbage til den orale bemægtigelsesdrift. Men herved sårer han sig selv, »und eine braune Flüssigkeit kam ihm aus dem Mund«. (s. 65). Munden som tidlig erogen zone repræsenterer altså her tarmzonen, og den orale fantasi overlappes herved af en anal fantasi om at være den passive $i$ en analt samleje, hvilket knytter an til Gregors passive driftsønsker i forhold til faren og den falliske kvinde.

Det samme kan iagttages, da Gregor snapper af den kaffe, som moren i rædsel har væltet. Kaffen er således kædet direkte sammen med moren, og drikkeriet synes at være en gentagelse af en oral-sadistisk indkorporering af moderbrystet. Men kaffen er brun, hvorfor den orale fantasi igen synes overlappet af en anal fantasi om indoptagelse gennem tarmen. Og idet denne fantasi er knyttet til moren, er det atter et udtryk for, at moren ikke opfattes som kastreret, men at den brune kaffe som repræsentant for hendes fækalier bliver symbol på penis.

\section{Gregors incestuфse sфsterfantasi}

Gregors tredie og sidste udbrud fra værelset er motiveret af en fascination af søsterens violinspil og følges op af et ønske om at få søsteren med sig ind på værelset. Omend Gregor forestiller sig at det skal ske frivilligt, er tvangen åbenlys, for Gregor »wollte sie nicht mehr aus seinem Zimmer lassen, wenigstens nicht, solange er lebte « (s.92). Og Gregor er nu ganske bevidst om, at han kan bruge sit væmmelige udseende som et våben:

»seine Schreckgestalt sollte ihm zum erstenmal nützlich werden; an allen Türen seines Zimmers wollte er gleichzeitig sein und den Angreifern entgegenfauchen« (s.92)

Forstillingen om angribere må nødvendigvis først og fremmest vare møntet på faren, som hele tiden har vist sig som den, der straffer Gregor og forsvarer husets kvinder. I dette perspektiv synes søsteren at fungere som en 
brik i den фdipale magtkamp. Dette kan underbygges med Gregors fantasi om søsterens reaktion på, at han på værelset vil fortælle hende om sin oprindelige plan om at sende hende på musikkonservatorium:

»Nach dieser Erklärung würde die Schwester in Tränen der Rührung ausbrechen, und Gregor würde sich bis zu ihrer Achsel erheben und ihren Hals küssen, den sie, seitdem sie ins Geschäft ging, frei ohne Band oder Kragen trug« (s.92).

Dette er mere end et broderligt kys, det er en erotisk dagdrøm. Og det er ikke første gang, at Gregor er fixeret på søsterens påklædning. Således allerede, da lægen skal hentes, hvor Gregor hører skørternes brusen og forundret tænker: "wie hatte sich die Schwester denn so schnell angezogen? « (s.64). Og en af de første gange søsteren træder ind i Gregors værelse, konstaterer han, at hun er »fast völlig angezogen« (s.72).

Den brik, som søsteren udgør i Gregors ødipale konflikt med faren, synes altså at være et surrogat for den elskede mor, hvilket da også nærmest virkeliggøres med søsterens faktiske påtagelse af de moderlige funktioner $i$ relation til den forvandlede Gregor. At Gregor ønsker at besidde søsteren seksuelt må antages at være den afgørende grund til at hun sluttelig formulerer en kategorisk afskrivning af ham, som eftertrykkeligt markeres, idet det er hende - og ikke faren - der efter Gregors tredie udbrud springer hen og låser døren efter ham.

\section{Søsterens $\emptyset$ dipuskompleks}

Men også Gregor fungerer som en brik i en magtkamp, nemlig i søsterens $\emptyset$ dipale konflikt. Hendes påtagelse af moderfunktioner er defineret af et $\emptyset n s k e$ om at etablere en passiv objektrelation til faren. Dette er tydeligt med hendes overdrevne og hysteriske resktion på, at moren en dag har rengjort Gregors værelse med vand. Det rasende udfald mod moren - især fordi det er til trods for at søsteren på dette tidspunkt i fortællingens kronologi synes at forholde sig nærmest ligegyldig overfor svineriet på Gregors værelse artikulerer en latent ødipal rivalisering. Ganske enkelt kan hun ikke acceptere morens indblanding. Udgangen på Gregors sidste udbrudsfors $\emptyset \mathrm{g}$ bekræfter til fulde den $\emptyset$ dipale struktur. Da Gregor fors $\emptyset$ ger at vende tilbage til varelset, oplever søsteren det som et fornyet forsøg på angreb og styrter fra moren "als wollte sie lieber die Mutter opfern, als ins Gregors Nähe bleiben, und eilte hinter den Vater, der ... die Arme wie zum Schutze der 
Schwester vor ihr halb erhob« (s.95, fremhævelsen er min) .

Det er tydeligvis faren, ikke Gregor, der er søsterens foretrukne kærlighedsobjekt. Gregors rolle for hende er en ganske anden. Hendes overtagelse af morens funktioner er udtryk for et forsøg på at omsætte substitutionsønsket i handling. I søsterens fantasi synes Gregor således ikke at være et barn af mor-far-relationen, men af hendes egen relation til faren. Gregors forvandling er for hende en enestaende chance til overfor faren at demonstrere sit kvindelige værd og udkonkurrere moren. Derfor ændrer hun sig fra at vare et unyttigt og selvoptaget pigebarn til en nyttig og handlekraftig kvinde og våger »mit einer an ihr ganz neuen Empfindlichkeit ... darüber, daß das Aufräumen von Gregors Zimmer ihr vorbehalten blieb« (s.88).

\section{De afgфrende bifigurer - de tre lejere}

Gregors sidste udbrud er fatalt, fordi det har søsterens afskrivning af ham som konsekvens, men også af en anden grund, nemlig konfrontationen med de tre herrer, som familien i deres $\emptyset$ konomiske nød har udlejet et værelse til. Disse tre herrer indtager en særeksistens i familien, som overstiger den opmærksomhed, der blev Gregor til del i tiden lige efter forvandlingen. De tre herrer har ganske enkelt erobret familierummet, dette især tydeligt $i$ forhold til husets to kvinder, hvorfor de fungerer som en visualisering af Gregors egen bemægtigelsestrang.

Men de tre herrer har tænder. Det har Gregor ikke. Tænder/tandløs artikulerer den pinefulde struktur fallisk/kastreret, hvilket $\mathbf{i}$ fortællingen betones, når Gregor oplever de tre herrers smaskeri under deres indtagelse af aftensmåltidet som en demonstration af, »daß man auch mit den schönsten zahnlosen Kiefern nichts ausrichten könne" (s.90, fremhævelsen er min).

Ganske enkelt fungerer de tre lejere med deres falliske karakter som en uhyggelig erkendelsesbefordrende instans. De făr ham til at erindre sin mangel, sin kastrerede tilstand, hvorfor oplevelsen ledsages af affekt: "Wie sich diese Zimmerherren nähren, und ich komme um!« (s.91).

Og da de tre herrer efterfølgende åbenlyst rivaliserer med Gregor, når de formår at få søsteren til at spille for sig, og endog i begyndelsen af seancen stiller sig "viel zu nahe (s.92) bag hendes nodepult, bryder han ud af værelset for ved en erobring af søsteren at demonstrere den falliske seksualitet, som faren har afskåret ham fra og stadig blokerer med de gentagne fordrivelser, der symboliserer kastration. For Gregor er det som om musikken viser ham vejen til »der ersehnten unbekannten Nahrung« (s.92), 
fordi violinen som både fallisk (strengen) og feminint (hulrummet) instrument $i$ den strygende bevægelse symboliserer samleje og derfor for Gregor virker som forførelse, som en invitation fra søsteren.

At erobringen ikke lykkes bliver hans død. De tre lejere har demonstreret hans mangel. $\mathrm{Nu}$ cementeres mangelen som et nederlag, hvorfor han betegnende nok hensattes i voldsom depressiv skuffelse over »das Mißlingen seines Planes« (s.94).

Da Gregor vender tilbage til værelset, strejfer hans sidste blik den sovende mor - det oprindeligt begarede objekt $i$ et afkald, fordi erobringen af den magt, som penis symboliserer, og dermed af farens plads i relation til moren, er umulig. Og samme nat dør han. Som en beslutning.

Men de tre falliske herrer udgør også en alvorlig trussel mod farens sociale og erotiske magtposition indenfor familien. Derfor jager han dem efter Gregors død kategorisk på porten med et »Verlassen Sie sofort meine Wohnung!« (s.97).

\section{Hushjalpen}

Det er den nye hushjælp, der har ladet døren stå åben ind til Gregors værelse og således indirekte opfordret ham til det sidste udbrud. Idet erobringen mislykkes for ham, bliver hushjælpen den figur, der indirekte udrydder ham, hvorved hun altså har allieret sig med faderloven. Hendes ansættelse, som sker kort efter søsterens udfald mod moren, synes da også at være farens gennemtvingelse af incestforbudet. Istedet for moren eller søsteren bliver det hende, en gammel enke, afseksualiseret og derfor meget lidt attraktiv og ganske uden angst eller afsky for Gregor, der som den eneste får lov til at gå ind $\mathrm{i}$ Gregors værelse. Et værelse, der har forvandlet sig til en hule for uhumskheder, og som af hushjælpen ovenikøbet anvendes som pulterrum og som affaldsrum for askespand og skraldespand.

Derved bliver Gregor container for familiens lort, dvs. for deres konfliktmateriale, det uønskede og utilladelige. Han er en fortrængningsfigur. Og en art symptombærer. Med hushjælpens hjælp inddæmmes den forbudte seksualitet $\mathrm{i}$ et nøje afgrænset rum og bortfejes endeligt med hans død. Hendes funktion som udrydder understreges, idet det er hende, som sørger for at han fjernes. Hvordan det sker, kan der kun gisnes om, omend den slagtersvend, der kommer op ad trappen, tydeligvis har en finger med $\mathrm{i}$ spillet. Hushjælpen er hjælper. Helt konkret. Hendes afskedigelse falder sammen med Gregors død, fordi hendes eneste opgave faktisk var at befordre en endelig udryddelse af ham. Og denne opgave er nu fuldbragt. 
Men der er nu også en anden grund til at hun afskediges: »Die fast aufrechte kleine Straußfeder auf ihrem Hut, über die sich Herr Samsa schon während ihrer ganzen Dienstzeit ärgerte « (s.98), symboliserer hendes falliske karakter. Faren ærgrer sig, fordi hun er en forstyrrer af den kønslige orden. Ganske som Gregor fornægter hun dikotomien fallisk/kastreret.

\section{Regredient fors $\phi g$ på emancipation}

Anskuet fra Gregors side opfatter jeg hermed »Die Verwandlung« som en artikulering af en umulig ødipal situation. Gregors oprindelige forsøg på progredient emancipation blokeres af farens fallit, der efterfølgende placerer Gregor i en ydmyg tjenende funktion som symbolsk kastreret. Hans aktive forsørgerrolle er dirigeret og defineret af faren, der samtidig fastholder sin fallisk-genitale position, sin autoritet indenfor familiens system. Gregor betaler af på farens gæld, hvilket er en opretholdelse af farens magtposition, dvs. også en understøttelse af farens seksuelle magt.

Forvandlingen er derfor et forsøg på regressiv emancipation fra den autoritære faderskikkelse. Det er en protest mod afmagten generelt og mod den symbolske kastration specifikt. Derfor kan søsteren efter Gregors andet udbrud fra værelset erklære: „Gregor ist ausgebrochen « (s.83). For Gregor er brudt ud af sin bestemmelse, sin ydmyge kastrerede position.

Gregors forvandling er primært en regression til det stadium i den psykoseksuelle udvikling, nemlig til analfasen, hvor Ødipuskomplekset dannes, hvor barnet indtræder i aktiv-passiv polariteten og artikulerer en indædt protest mod enhver beherskende magt, samt til den aktivt-falliske fase, hvor Ødipuskomplekset udvikler sig til et kastrationskompleks. Især disse to seksualorganisationer overlapper og virker ind på hinanden $\mathbf{i}$ »Die Verwandlung«.

Idet forvandlingen fungerer som en forhindring for Gregor $\mathrm{i}$ at aflægge penge og betale farens gald, bliver pengene/betalingens symbolske betydning evident. Det er en hævnaktion, en manifestation af netop det sene anal-sadistiske jeg's tilbageholdelse af ekskrementer. Denne tilbageholdelse kan være overlappet af en samtidig fallisk fantasi om at betalingen/defækationen er ensbetydende med tab af penis.

I dette perspektiv symboliserer galden, som æblet, Gregors ødipale skyld og farens krav mod den søn, der med forvandlingen har brudt den sociale kontrakt og forsøger at bryde incestforbudet.

Skylden manifesterer sig som bl.a. samvittighedsangst, hvilket netop bevidner det $\emptyset$ dipale jeg's eksistens, videreført i skikkelse af et straffende 
overjeg. Gregors pligtopfyldende og selvudslettende, ret beset hans tvangsneurotiske, adfærd f $\varnothing \mathrm{r}$ forvandlingen, samt stadig efter forvandlingen, fungerer som en reaktionsdannelse mod de anal-sadistiske og falliske affekter.

Det samme galder hans omvending af de aktive driftsmål til passive, der desuden er en reaktion på kastrationsfaren. Især Gregors fetichisme er et desperat forsvar herimod. Ved denne partiale realitetsfomægtelse fors $\varnothing$ ger han at fornægte muligheden af kastration overhovedet. En fornægtelse, der søges opretholdt til det sidste. Gregor er symbolsk kastreret fra begyndelsen, men da de tre lejere konfronterer ham med denne realitet, søger han at ophæve den ved at bryde ud af værelset, motiveret af et ønske om at bemægtige sig søsteren og derved demonstrere sin falliske seksualitet. Da det heller ikke denne gang lykkes, dør han. Gregors død kan i dette perspektiv anskues som en accept af skylden og dermed også som en endelig tilbagebetaling af den ødipale gald.

\section{Genetableringen af den faderlige orden}

Reaktionen på Gregors død er lettelse og taknemmelig: »jetzt können wir Gott danken « (s.97), siger Gregors far, og taksigelsen ledsages af religiøs ritualisering hos alle de tilstedeværende. Herved bliver borgerlig kontrakttænkning forenet med religiøs pagttænkning, hvilket tilkendegiver, at Gregors forvandling er at opfatte som et brud på såvel den guddommelige lov som farens familieorden. Forvandlingen har bragt djevlen ind i familien, klart tilkendegivet med kaosmetaforikken i forbindelse med allerede Gregors første udbrud fra værelset, hvor moren river et vindue op:

"Zwischen Gasse und Treppenhaus entstand eine starke Zugluft, die Fenstervorhänge flogen auf, die Zeitungen auf dem Tische rauschten, einzelne Blätter wehten über den Boden hin« (s.69).

I overensstemmelse med at moren er begarsobjektet $\mathrm{i}$ det ødipale trekantsdrama er det hende, der lukker djævlen ind. Men det er Gregor selv, der har bedt ham komme: "Der Teufel soll das alles holen!« (s.57). Og denne djævel, Gregors forbudte og derfor fortrængte drifter, lukkes ind om efteråret - årstiden for den døende gud (jfr. her farens forfald). Som en bekræftelse af fortællingens mytiske undergrund er det omvendt forår - »Es war eben schon Ende März« (s.97) - da Gregor dør. Hele vinteren har underverdenens dæmoniske kræfter, ganske som i den mytiske forståelse af 
vinteren som årstiden for kaos og opløsning, behersket "familieparadiset«. Forvandlingen gennemspiller herved årstidsmyterne, helt præcist tre årstider, hvilket er $\mathbf{i}$ overensstemmelse med den generelle tretalssymbolik, som præger og endog strukturerer fortællingen: Tre kapitler, tre udbrud fra værelset, tre fordrivelser, tre lejere. Og ikke mindst - den ødipale trekant. Tretallet er i sig selv symbol på død og genfødsel/forvandling. Her konkretiseres det med årstidsforløbets symbolisering af samme proces.

Forvandlingen bringer kaos, forstyrrelse af den køns- og generationsspecificerede orden $\mathrm{i}$ familien som helhed. Idet denne orden imidlertid genoprettes med Gregors død, synes Kristusmyten at udspille sig som den definitive afslutning på den syndefaldsmyte, som farens æblebombardement effektuerer, hvilket understreges med netop den religiøse ritualisering - og ikke mindst af, at Gregor som døende når at opleve "Den Anfang des allgemeinen Hellerwerdens draußen vor dem Fenster « (s.96).

Gregors død er familiens forår og genfødsel, fordi Gregor tager skylden på sig og derved forvandles fra inkarnationen af det dæmoniske til en mere guddommelig skikkelse. Hans død betyder en ny begyndelse, en genetablering af den lille (familiens) og den store (guddommelige) faderlige orden, og får sit konkrete udtryk med forårets begyndelse, med familiens rejse »ins Freie vor die Stadt« (s.99), samt med forældrenes uudtalte indforståelse med, at de må finde en brav mand til den »üppigen Mädchen« (s.99), som søsteren er blevet. Dét indikerer et, i modsætning til Gregor, overvundet $\varnothing$ dipuskompleks. Hendes seksualitet kan og må kanaliseres ud af familiens lukkede system. Samtidig er det i dette tilfælde en understøttelse af den borgerlige ideologi: seksualiteten plejet (og tæmmet) indenfor et patriarkalsk defineret og kristent velsignet ægteskab.

Noter

1. Ordet 'far' bruges $i$ to betydninger, hvorfor der også anvendes to stavemåder. 'Far' og 'faren' henviser til fortallingens konkrete far, mens 'fader' og 'faderen' henviser til den symbolske fader og faderloven.

2. Sidetallene henviser til Franz Kafka: Sämtliche Erzählungen, Frankfurt a. M., 1989. 


\section{Litteratur}

Binder, Hartmut: Kafka. Der Schaffensprozeß. Frankfurt am Main 1983.

Fingerhut, Karl-Heinz: Die Funktion der Tierfiguren im Werke Franz Kafkas. Bonn 1969.

Freud, Sigmund: Das Ich und das Es Und andere metapsychologische Schriften. Frankfurt am Main 1988.

Freud, Sigmund: Drei Abhandlungen zur Sexualtheorie Und verwandte Schriften. Frankfurt am Main 1988.

Freud, Sigmund: Psykoanalyse. Samlede forelasninger. Kbh. 1990.

Freud, Sigmund: Drømmetydning, bd. 1 og 2. Kbh. 1985.

Højholt, Per og Johansen, Ib m.fl.: Essays om Kafka. Århus 1983.

Johansen, Jørgen Dines: Psykoanalyse, litteratur, tekstteori, bd. 1 og 2. Kbh. 1977.

Kafka, Franz: Sämtliche Erzählungen, Die Verwandlung s. 56-99. Herausgegeben von Paul Raabe. Frankfurt am Main 1989.

Kurz, Gerhard: Traum-Schrecken. Stuttgart 1980.

Olsen, Ole Andkjær og Købbe, Simo: Freuds psykoanalyse. Kbh. 1987.

Olsen, Ole Andkjær: Ødipus-komplekset. Kbh. 1988.

Politzer, Heinz (red.): Franz Kafka. Wege der Forschung. Darmstadt 1973.

Schubiger, Jürg: Franz Kafka: Die Verwandlung. Zürich und Freiburg 1969.

Sokel, Walter H.: Franz Kafka - Tragik und Ironie. München, Wien 1964. 